\title{
10. The Courts, the Churches, the Witches and their Killers
}

\author{
Christine Stewart
}

\section{Introduction}

This chapter discusses the approaches of the formal legal system of Papua New Guinea (PNG) to cases of witch-killing, from colonial times to the present. The title is based on that of a movie from more than 20 years ago, entitled The Cook, the Thief, His Wife and Her Lover, a movie I saw accidentally and found totally gruesome and unappealing. But this adaptation of the title seemed apt, because there are some very gruesome aspects to witch-killing in PNG today (Forsyth 2013).

\section{Sorcerer versus witch, victim versus killer}

First, some matters of terminology and categorisation. What is the difference between a sorcerer and a witch? It is difficult to generalise across the many and varied cultures of PNG (Reay 1976; see also Stephen 1987). Practitioners may be differentiated in various ways; for example, sorcerers are usually but not always male, witches may or may not always be female. Different means may be employed to achieve the desired end, which could be injury, damage or death or, conversely, to produce a positive outcome such as love requited or a successful harvest. Skills may be acquired in different ways - learned from a relative, or through possession by some form of malicious spirit creature. They may be used for good or bad, sometimes only against enemies or strangers, sometimes only against other members of the practitioner's social group, sometimes against anyone.

The general consensus among those who write on the topic in relation to PNG today is that a sorcerer is usually a male who possesses skills which have been learned, often from a male relative, and which may be used for good or bad, but are often only used for good, whereas malevolent sorcery may or should only be used against enemies. A witch, on the other hand, may be either a male or female who has been possessed by some form of evil spirit creature, and who uses evil magic against anyone, because he or she is not in full control (Gibbs 2012). 
These are very generalised definitions, which may not hold true in all societies or at all times. In this chapter, I have used the terms interchangeably as fits the context. I will also be talking only of bad or 'black' magic.

A more problematic question is who is the killer, who is the victim? The term 'witch-killing' can be understood in two opposed ways: the killing (or other harm) that is done by practitioners of sorcery; and the killing of sorcerers and witches by individuals or communities (Zocca 2009).

\section{Witch-killing in Europe}

PNG's formal legal system, derived from that of Europe in general and England in particular, has by various means tried to tackle both issues. It is relevant and revealing therefore to consider the history of witch-killing in Europe, where the condemnation of sorcery and witchcraft has a long history, stretching from the fourth to the eighteenth century (Bailey 2008; see also Briggs 1996). The early Christians believed that Christ came partly to overcome superstition and demonic pagan magic. From the sixth to the early eleventh century, magic was paganism except for healing practices. If Christianity approved it, it was not magic, it was something inspired by natural forces or divine power. Harsh punishments were imposed upon magic and its practitioners, but states at that time were fluid and lacked the powers to enforce their laws.

However, during the high medieval period of the eleventh and twelfth centuries, states stabilised, bureaucracies expanded, Roman law was reintroduced and combined with existing systems, canon and church law became more highly developed and the views of the educated elites diverged from those of the grassroots. The ruling classes started identifying and punishing marginal groups, including practitioners of magic. Earlier accusatorial procedures had placed the burden of proof on the accuser, which made it hard to prove the covert practices of magic. Despite trial by ordeal, the accuser was in a difficult position: if he failed to prove his case, he himself was often subject to prosecution.

Then in the twelfth and thirteenth centuries, churches became more organised and bureaucratic. Intellectual revival began, schools and then universities were founded, and legal and intellectual structures for understanding magic were developed. The inquisitorial system was introduced to investigate heresy. This placed the burden of proof onto the tribunal, which could act on accusation or even mere suspicion. Sorcery and witchcraft were classed as heresy, and witch trials became more common. They were conducted mainly by secular courts, required strict standards of proof, and usually involved torture, derived from Roman law, to extract confessions. 
By the fourteenth and fifteenth centuries, concerns about magical practices were growing. This period saw the beginnings of the earliest real witch trials. The Renaissance of the fifteenth and sixteenth centuries brought new understandings of magic based on the rediscovered texts of antiquity. Protestantism in England reconceived how divine power operated and brought new reliance of spells and more intense fear of witches and demonic attack. This saw the era of massive witch-hunts, although it should be emphasised that these were aberrant social movements, rather than the norm. Gradually, belief in magic and witchcraft faded, particularly among the ruling classes, and legal sanctions against witchcraft were repealed by the eighteenth century. Nevertheless, beliefs and practices still persisted, mainly among the grassroots population, and the Christian churches, in England at least, still oppose witchcraft.

\section{Witch-killing in the colony}

This then was the background to the laws introduced into the colonies of PNG. Like their European Christian ancestors before them, the first colonists were greatly troubled by the widespread ${ }^{1}$ evidence of sorcery beliefs and practices they found in PNG (Barker 2007; Dalton 2007; Sack 1974). Because they believed that their civilising mission would be largely achieved by the introduction of the Western legal system, they sought to prevent the practice of sorcery by the law. But from the outset, they had difficulty trying to prohibit something that they believed did not exist. ${ }^{2}$

An early attempt to resolve the situation was made by the first administrator of what was then British New Guinea, at the end of the nineteenth century. He tried to justify the anti-sorcery provisions that were written into the Native Regulations, ${ }^{3}$ by prefacing the sorcery offences with the statement that

Sorcery is only deceit, but the lies of the Sorcerer frighten many people and cause great trouble, therefore the Sorcerer must be punished. ${ }^{4}$

\footnotetext{
1 The cases discussed in this chapter come from all provinces except East Sepik, Manus and New Ireland. However, this is not to say that sorcery is not practised in these provinces.

2 The problem was later confronted by the framers of the Sorcery Act 1971, when the original elegantly brief Bill had to be expanded greatly to ensure that judges and magistrates were not to be taken as actually believing in the sorcery discussed in cases that came before them.

3 I use this as a compendium term for the Native Regulations made in British New Guinea beginning 1888, then in Papua under the Native Regulation Act 1908-1967 (Papua), and in New Guinea under the Native Administration Regulations made under the Native Administration Act (New Guinea) (Chapter 315). Daily village life in both territories was governed in minute detail by means of these regulations, which were constantly being varied and updated and the colonising enterprise expanded.

$4 \quad$ Native Regulations 1922 (Papua), R 87.
} 
The Native Administration Regulations of New Guinea were not made until 1924, several years after Australia assumed the administration of what was then the Mandated Territory. The regulations omitted the original homily, but otherwise were similar in both territories, for example:

Any native who -

(a) practices or pretends to practice sorcery; or

(b) threatens any person with sorcery whether practised by himself or any other person; or

(c) procures or attempts to procure any other person to practise or pretend to practise or assist in sorcery; or

(d) is found in possession of implements or "charms" used in sorcery; or accepts payment or presents in the shape of food or otherwise when the obvious intention of making such payments or presents is to propitiate a Sorcerer,

shall on conviction be liable ... ${ }^{5}$

Sir Hubert Murray, who was the second administrator of Papua until his death in 1940, went further than a mere imposition of the beliefs of Western society. He studied Papuan societies in quite some detail, and noted that although twentieth-century Europeans do not accept that sorcery is a reality, nevertheless the Papuans do, and feel no guilt for killing a sorcerer. As well as malicious sorcery, Papuans also believe in 'good' sorcery, such as for prosperous gardening, hunting and fishing, and to manage the weather. Murray thought that people were frightened to give out information on sorcerers, for fear of retaliation from the sorcerer (although he may have overlooked the fact that they may also have been motivated by a fear that they would not be believed). As far as management by the introduced formal law system went, he realised that the six-month penalty in the regulations was quite insufficient as a substitute for private vengeance, and wondered whether the suppression of payback killings and tribal warfare had actually promoted the use of sorcery (Murray 1912:203-6).

\section{The law and the killing of witches}

\section{The real crime}

The Native Regulations, which applied to indigenous inhabitants only, prohibited the practice of sorcery by an alleged sorcerer. The more serious

5 Native Regulations 1939 (Papua) Section 80(2). 
(and in the colonists' view, more real?) matter of killing the sorcerer already fell squarely within the ambit of the Criminal Code. Witch-killing was clearly murder in the eyes of the law. Various strategies were attempted by defence counsel to mitigate the murder charges against witch-killers. The first attempt was one of insanity, on the basis that a primitive belief in sorcery indicated a state of natural mental infirmity, but this was rejected. ${ }^{6}$ A few years later the courts $^{7}$ decided that a belief in sorcery is not a reasonable belief, so there can be no defence of mistake of fact within the meaning of the Criminal Code. Nor was a witch-killing an act of self-defence or defence in aid. These defences only operate in situations of assault, and it was held that a sorcery attack does not constitute an assault. A few years later, the case of $R v$. K.J. \& Anor ${ }^{8}$ suggested that a defence of provocation could succeed, but only if the killing occurred in the heat of passion.

\section{The mitigation factor}

Clearly though, to treat witch-killers as ordinary murderers when they were operating under a different belief system was unjust. Many cases of witchkilling arose in remote areas, barely touched by education or mission. How could these people be made to understand what this alien law says? Writing in 1930, Justice Gore of the Papua Central Court opined that

The native becomes a criminal only because of the law which somebody, of whom he has never heard, has imposed upon him. In justice the Court cannot award any punishment at all ... In order that punishment should deter through the terror it inspires the delinquent must know that he is doing wrong ... It is through the attitude of the Courts in their treatment of the criminal sanctions in relation to native crime that the necessary adjustment is made between the sanctions provided and the social condition existing. (Gore 1932:20-21)

Thus the colonial courts came to treat a genuine belief in sorcery not as a defence against the charge but as a special factor to be considered in mitigation of sentence after the accused has been convicted of his crime. In 1963, the Native Customs (Recognition) Ordinance ${ }^{9}$ was enacted, and permitted custom to be taken into account in criminal cases, again not as a defence but only to determine the reasonableness of a belief or state of mind, or when considering sentence. The ordinance confirmed that a belief in sorcery operated in mitigation of sentence, once the witch-killer was found guilty. This tactic was supposed to relate the foreign criminal law to the circumstances of its adopted home (O'Regan 1974:77).

\footnotetext{
$R v$. Womeni-Nanagawo [1963] PNGLR 72.

R v. Manga-Kitai [1967-68] PNGLR 1; R v. Ferapo-Meata (Unreported, SC419, March 1967, Clarkson J).

R v. K.J. \& Anor [1973] PNGLR 93.

Now renamed the Customs Recognition Act.
} 
Talking it Through

\section{The Sorcery Ordinance 1971}

Meanwhile, in 1971, the Sorcery Ordinance ${ }^{10}$ was passed. Its language drew heavily on that of the Native Regulations cited above. Its main aim was to give jurisdiction to the formal courts to prosecute acts of sorcery, along the lines already provided in the Native Regulations, which were due to be repealed at Independence. But it also included a provision that enabled a defence of provocation to a charge of murder for killing a witch. This defence has the effect of reducing a charge of murder to one of manslaughter, and it is this factor that has troubled so many recently, prompting the repeal of the Sorcery Act 1971 in 2013.

\section{The prosecution of sorcery}

The Sorcery Ordinance was mainly aimed at working towards stamping out sorcery practices by legal action in the formal courts. It contained a lengthy preamble to justify itself, as follows:

There is a widespread belief throughout the country that there is such a thing as sorcery ... and because of this belief many evil things can be done and many people are frightened ... it is necessary for the law to distinguish between evil sorcery and innocent sorcery ... a person who uses or pretends or tries to use sorcery to do ... evil things should ... be punished just as if sorcery and the powers of sorcerers were real.

The original Bill was drafted in only five clauses. But magistrates, lawyers and judges wanted protection from accusations that by trying a sorcery case, they would be taken to believe in sorcery themselves. So the final version (Section 5) provided that nothing in the law either recognised or denied the existence or effectiveness of sorcery.

But there was a bigger problem with trying to deal with sorcery in the formal court system. It is a basic principle of the law that sorcerers should be brought to justice and not killed by self-help, but subsequent cases ${ }^{11}$ have shown how hard it is to use the processes of the introduced law, particularly the evidentiary requirements, to convict a witch or sorcerer for killing by supernatural powers. This set the stage for continued acts of witch-killing, so long as sorcery beliefs persisted.

In 1974, when village courts were established to adjudicate on custom, they too were given powers to prosecute crimes of sorcery, comprising:

(i) practising or pretending to practise sorcery; or

10 Renamed the Sorcery Act after Independence.

11 State v. Noah Magou [1981] PNGLR 1; State v. Dickson Miritok (Unreported, N3466, 2007, Kandakasi J). 
(ii) threatening any person with sorcery practised by another; or

(iii) procuring or attempting to procure a person to practise or pretend to practise, or to assist in, sorcery; or

(iv) the possession of implements or charms used in practising sorcery; or

(v) paying or offering to pay a person to perform acts of sorcery. ${ }^{12}$

Village courts did not need to follow strict rules of evidence and procedure, which made it easier to prove sorcery in a village court than in the state courts using the Sorcery Ordinance.

\section{Custom and the killing of witches}

In the colonial period, customary belief in sorcery was more or less automatically accepted by the courts. However, the administration and the expatriate judges were sure that education and the influence of Christianity would eventually stamp out such beliefs, and believed there was already evidence of this process. Witch-killing cases at this time were decided on the basis that the degree of sophistication, or lack of it, affected the sentence. ${ }^{13}$

After Independence though, the suspicion started growing that sorcery practices may not be dying out. The Law Reform Commission in 1977 noted that sorcery may be increasing, and thought that this might be 'as a result of the uncertainties involved in modern development or underdevelopment' (LRCPNG 1977). In 1981, the Supreme Court (PNG's highest court of appeal) observed that education and sophistication had not stamped out sorcery beliefs. ${ }^{14}$

At this stage, enter Acting Justice Bernard Narokobi, the first chairman of the Law Reform Commission at the time of Independence. He had had a large input into the Constitutional Planning Committee Report, and wrote extensively of his dream of an indigenous jurisprudence which would combine the best of Melanesian custom, human rights principles and Christian belief (Narokobi 1977, 1980, 1982, 1989a, 1989b). He was an acting judge of the National Court in 1980-81, and tried in many ways to encourage his brethren on the bench to work towards devising a legal system which incorporated due respect for custom.

12 Regulation 3(p), Village Courts Regulation 1974.

13 For example, Queen v. Asis \& Bitimur (Unreported SC559, 1970, Clarkson J); Wanosa \& Ors v. The Queen [1971-72] PNGLR 90; Secretary for Law v. Ulao Amantasi \& Ors [1975] PNGLR 134.

14 Agoara Kebo v. State (Unreported, SC198, 1981, Kidu CJ Kapi Miles J). 
Acting Justice Narokobi dealt with several cases of witch-killing. In Luku Wapulae's Case, ${ }^{15}$ five men killed a woman sorceress at Porgera, in Enga Province in the highlands. But they expressed no remorse, as they believed she had killed many people and it was an act of honour to rid the community of such a threat to the wellbeing of all. The judge drew an analogy with the way the nation through its laws and its health system declares war on germs that are responsible for sickness and disease. If at the local level sorcerers are believed to be responsible for deaths, he said, it was not difficult to see that the community would want to defend itself from this disease. He devised a defence of 'diminished responsibility', based on a Law Reform Commission recommendation, and ordered a three-month gaol sentence and a compensation payment of pigs. Then the following month, he tried to use custom to change the imported law by giving weight to the evidence of dreams that had led the accused to kill a suspected witch. ${ }^{16}$

But the Supreme Court wasn't interested in considerations of customs and their underlying philosophy. It held that to award compensation, even in an area as remote as that in which the killing took place, was unconstitutional; that there was no such thing as a defence of 'diminished responsibility'; and that the sentence for 'payback' killing was far too light. ${ }^{17}$ Narokobi's attempts at law reform were unsuccessful.

\section{Victim or perpetrator?}

In a steady line of cases from the decolonisation era onward the defence has argued that the killers were acting in the belief that they were defending the community. ${ }^{18}$ Sometimes, the whole community gathered and agreed that in order to save the people, the sorcerer should be put to death. One judge acknowledged this explicitly in 2006, when he said:

To act on behalf of the community to commit a serious crime [such] as the one under consideration takes or requires so much courage on the part of actors as was the case of the two accused. ${ }^{19}$

\footnotetext{
15 State v. Luku Wapulae (Unreported, N233, 1980, Narokobi AJ).

16 State $v$. Yale Gesie (Unreported, N254, 1980, Narokobi AJ).

17 Acting Public Prosecutor v. Uname Aumane \& Ors [1980] PNGLR 510. This case is critiqued in depth in Zorn (2006).

18 Wanosa \& Ors v. The Queen [1971-72] PNGLR 90; Secretary for Law v. Ulao Amantasi \& Ors [1975] PNGLR 134; State v. Luku Wapulae (Unreported, N233, 1980, Narokobi AJ); State v. Aigal [1990] PNGLR 318; State v. Boat Yokum \& Ors (Unreported, N2337, 2002, Injia J); State v. Saweno Visare \& Ragu Maioi (Unreported Unnumbered), CR.NO.1455 of 2005, 15 June 2006, Lenalia J.

19 State v. Saweno Visare \& Ragu Maioi (Unreported Unnumbered), CR.NO.1455 of 2005, 15 June 2006, Lenalia J.
} 
In this case, the accused had already pleaded guilty to wilful murder by complicity, but referred to their belief that they were defending the community, which prompted the judge's reflections on the matter. Nevertheless, he imposed a 15-year sentence in accordance with the Supreme Court's sentencing tariffs.

\section{Custom or human rights?}

This defence raises an interesting philosophical problem, one that the common law system was ill-equipped to handle: what is more important, protecting the individual or protecting the community? The usual way in which the postcolonial courts have countered the custom and community defence argument has been by reference to the individual human rights enshrined in the constitution, in cases almost to the present time. ${ }^{20}$ Rights most commonly upheld are the right to life, the right to freedom from torture, the right to the protection of the law and a fair trial, and the test that witch-killing is repugnant to the general principles of humanity. While these rights continue to be raised in aid of mitigation of sentence, they have, over the past decade, been accompanied by reference to judicial opinion that witch-killing is also contrary to the beliefs and precepts of Christianity.

\section{Christianity and the killing of witches}

The preamble to the Constitution states that 'We, the people of Papua New Guinea ... pledge ourselves to guard and pass on to those who come after us our noble traditions and the Christian principles that are ours now'. These days, this is often taken to mean that 'Papua New Guinea is a Christian nation'.

The courts have always incorporated references to Christian principles into their decisions. This stems from the earliest days of the colony, when the missions were viewed as part of the 'civilising' process that would see sorcery beliefs die out. But this theory did not hold true. In 1983, Chief Justice Kidu noted in State $v$. Aiaka Karavea ${ }^{21}$ that while courts had once presumed a conflict between the belief in sorcery and the introduced law, nowadays even the besteducated people believe in sorcery. In other words, it has become a question not of custom or Christianity, but custom and Christianity. The early hopes of the colonial administration, that Christianity would replace sorcery, had been

\footnotetext{
20 Acting Public Prosecutor v. Uname Aumane \& Ors [1980] PNGLR 510; State v. Yale Gesie (Unreported, N254, 1980, Narokobi AJ); State v. Aiaka Karavea and Lelehua Karavea (Unreported, National Court, N452, 1983, Kidu CJ); State v. Aigal [1990] PNGLR 318; State v. Muare Kiage (Unreported, N918, 1990, Brunton J); State v. Siune Arnold (Unreported, N1658, 1997, Batari AJ); State v. Urari Siviri (Unreported, N2747, 2004, Batari J); State v. Maraka Jackson (Unreported, National Court, N3237, 2006, Kandakasi J); Irai Thomas v. State (Unreported, Supreme Court, SC867, 2007, Kandakasi, Lenalia and David JJ).

21 State v. Aiaka Karavea and Lelehua Karavea (Unreported, National Court, N452, 1983, Kidu CJ).
} 
confounded. Siviri's Case C $^{22}$ in 2004 evidenced a melding of sorcery and Christian beliefs, when a suspected witch was killed in church grounds in the presence of the pastor. Rather than overcoming and supplanting customary beliefs and practices, it seemed that Christian doctrine had been incorporated into them.

But the courts, by now almost entirely consisting of PNG judges, have resisted this suggestion. More than 10 years ago, in 2002, Justice Injia (later to become chief justice) declared that:

belief in the power of witchcraft and belief in the power of the Christian God cannot exist side by side. One belief system has to give way to the other. ${ }^{23}$

He thought that witch-killing is pure payback and included in his sentence an order for intensive Christian training of the witch-killers. Another judge took into account the fact that the accused was a Christian pastor, and refused to allow any belief in sorcery to mitigate sentence. ${ }^{24}$ Yet another judge denied the belief outright, saying, "There is no such thing as sorcery. It only exists in the mind of a person and does not exist in fact. ${ }^{25}$

But despite the arguments of defence of the community, and the incorporation of much of Christian doctrine into the ever-changing precepts of custom, the judges were clearly getting tired of witch-killing. They started questioning the 'mitigation factor'. With increased education, mission influence and sophistication, why should a belief in sorcery still be a special factor in mitigation $?^{26}$ And in fact, not long ago the Supreme Court decided that it was no longer automatically a 'special' mitigating factor. Henceforth mitigation of sentence would depend on the facts of each case. ${ }^{27}$ Finally in 2007, in a particularly nasty case of witch torture and killing, the death penalty was imposed..$^{28}$ And as recently as 2013, a newspaper report claimed that a man in Enga Province had been sentenced to 30 years in jail for killing his aunt on suspicion of sorcery. The killing was described as 'senseless, barbaric and brutal' (The National 2013). The judges had come to appeal not to customary principles and human rights, but to those principles expounded as 'Christian principles'.

\footnotetext{
22 State v. Urari Siviri (Unreported, N2747, 2004, Batari J).

23 State v. Boat Yokum \& Ors (Unreported, N2337, 2002, Injia J).

24 State v. Baipu (Unreported, N2451, 2003, Jalina J).

25 State v. Prodie Akoi \& Steven Akoi (Unreported, N2584, 2004, Kandakasi J).

26 State v. Urari Siviri (Unreported, N2747, 2004, Batari J); see also State v. Prodie Akoi \& Steven Akoi (Unreported, N2584, 2004, Kandakasi J); State v. Maraka Jackson (Unreported, National Court, N3237, 2006, Kandakasi J).

27 Irai Thomas v. State (Unreported, Supreme Court, SC867, 2007, Kandakasi, Lenalia and David JJ).

28 State v. Sedoki Lota \& Fred Abenko (Unreported, N3183, 2007, Sevua J).
} 


\section{To sum up}

From early Christian times, the law in European states was directed at prosecuting sorcerers and witches. This trend was exported in the English common law to colonial PNG, where laws were made to prosecute acts of sorcery, although it proved difficult to prosecute sorcerers successfully under the introduced legal system, so self-help was actually encouraged.

The introduced law also prosecuted witch-killers as murderers, although a genuine belief in sorcery was a special factor in mitigation of sentence. But this introduced legal system focused on the rights and responsibilities of the individual and ignored customary principles of responsibility to the general community, where to kill a witch was viewed as protecting the community.

It was initially assumed that with education and modernisation, sorcery beliefs would die out, but after Independence, sorcery beliefs did not diminish with greater education, and co-existed with Christianity. However, the courts refused to accept that the two belief systems could co-exist, and prosecuted witch-killers even more strongly. Recently, the Supreme Court rejected the automatic special mitigation factor, sentences became heavier, and the National Court imposed a death sentence.

It is interesting to contrast this line of reasoning with that of Western European societies of the past two millennia, in which torture and killing of witches were carried out in the name of Christianity. In PNG, Christianity has been set in contradistinction to customary beliefs. But despite more than a century of attempts by the law and Christianity in PNG to deal with witch-killing, neither has managed to deal completely with the underlying question: Who are the criminals? The sorcerers? The diviners? The accusers? The torturers? The killers? The whole community? (Zocca 2009).

Nevertheless, it is possible that this latest trend in judicial opinion can indicate a way forward, not through specific legal action but through the deployment of Christian doctrine, preaching and prayer. Already there are some signs that this strategy is being used to good effect. Further judicial support along these lines is to be encouraged. 
Talking it Through

\section{References}

Bailey, M.D. 2008. The Age of Magicians. Magic, Ritual and Witchcraft 3(1):1-28.

Barker, J. (ed.) 2007. The Anthropology of Morality in Melanesia and Beyond. Aldershot, England: Ashgate.

Briggs, R. 1996. Witches and Neighbours: The Social and Cultural Context of European Witchcraft. London: HarperCollins.

Burridge, K. 1995. Mambu: A Melanesian Millennium. Princeton, NJ: Princeton University Press.

Dalton, D. 2007. When Is It Moral To Be a Sorcerer? In J. Barker (ed.) The Anthropology of Morality in Melanesia and Beyond. Aldershot, England: Ashgate, 39-55.

Forsyth, M. 2013. Witchcraft and Sorcery-Related Killings in Melanesia: The Legal Issues. SSGM In Brief 2013/1. Canberra: State, Society and Governance in Melanesia Program, The Australian National University.

Gibbs, P. 2012. Engendered Violence and Witch-Killing in Simbu. In M. Jolly, C. Stewart and C. Brewer (eds.) Engendering Violence in Papua New Guinea. Canberra: ANU E Press, 107-35.

Gore, R.T. 1932. The Punishment of Crime among Natives. Territory of Papua Annual Report 1930-1931. Canberra: Parliament of Australia, 20-22.

LRCPNG (Law Reform Commission of Papua New Guinea) 1977. Sorcery. Occasional Paper No. 4. Waigani: LRCPNG.

Murray, H. 1912. Papua or British New Guinea. London: T. Fisher Unwin.

Narokobi, B. 1977. Adaptation of Western Law in Papua New Guinea. Melanesian Law Journal 5(1):52-69.

Narokobi, B. 1980. The Melanesian Way: Total Cosmic Vision of Life. Boroko: Institute of Papua New Guinea Studies.

Narokobi, B. 1982. History and Movement in Law Reform in Papua New Guinea. In D. Weisbrot, A. Paliwala and A. Sawyerr (eds.). Law and Social Change in Papua New Guinea. Sydney: Butterworths, 13-24.

Narokobi, B. 1989a. Lo Bilong Yumi Yet: Law and Custom in Melanesia. Suva: Institute of Pacific Studies of the University of the South Pacific and The Melanesian Institute for Pastoral and Socio-Economic Service. 
Narokobi, B. 1989b. Law and Custom in Melanesia. Pacific Perspectives 14(1):17-26.

National, The 2013. Killer Gets 30-Year Term. The National online, 22 April. www.thenational.com.pg/?q=node/48739.

O'Regan, R.S. 1974. Sorcery and Homicide in Papua New Guinea. Australian Law Journal 48:76-82.

Reay, M. 1976. The Politics of a Witch-Killing. Oceania 47(1):1-20.

Sack, P.G. 1974. Crime or Punishment: The Role of the Sorcerer in Traditional Tolai Law (New Britain). Anthropos 69(3/4):401-8.

Stephen, M. (ed.) 1987. Sorcerer and Witch in Melanesia. Melbourne: Melbourne University Press.

Zocca, F. (ed.) 2009. Sanguma in Paradise: Sorcery, Witchcraft and Christianity in Papua New Guinea. Point No. 33. Goroka: Melanesian Institute.

Zorn, J.G. 2006. Women and Witchcraft: Positivist, Prelapsarian, and PostModern Judicial Interpretations in PNG. In A. Whiting and C. Evans (eds.) Mixed Blessings: Laws, Religions, and Women's Rights in the Asia-Pacific Region. Leiden: Martinus Nijhoff, 61-99. 
This text is taken from Talking it Through: Responses to Sorcery and Witchcraft Beliefs and Practices in Melanesia, edited by Miranda Forsyth and Richard Eves, published 2015 by ANU Press, The Australian National University, Canberra, Australia. 